\title{
Sacred architecture in the area of historical Volhynia
}

\author{
Liliia Gnatiuk ${ }^{1, *}$ \\ ${ }^{1}$ National Aviation University, Interior Design Department, Faculty of architecture, construction and \\ design, Kyiv, Ukraine
}

\begin{abstract}
This article discusses the genesis and historical development of the sacred complexes of historic Volhyn. Based on historical and architectural analysis, it is presented that sacred complexes of historic Volhynia were built according to the canons of temple architecture, and at the same time they have their own characteristics, related to national traditions and regional features which appeared as a result of the process of forming Christianity as a religion associated with national development in the specific study territory. The results of a comprehensive analysis of historical and archival documents found in the archives of Ukraine, Poland and Russia, as well as field research are presented. Results of system and theoretical research of significant retrospective analysis of canonical, historical and political prerequisites of sacral complexes were generalized. The concept of sacred complex structures throughout XI-XIX th centuries is suggested in correlation with the change of religious identity formation and differentiation according to religious requirements. Existence of autochthonous traditions and genuine vector of the Volhynia's sacred complex development, considering the specific geopolitical location between East and West in the area where two different cultures collide with each other has been proved. The work is shifting statements concerning direct borrowing of architectural and stylistic components of architectural and planning structure and certain decorative elements.
\end{abstract}

\section{Introduction}

Architecture more than other forms of art reflects the state of society, its political level, the degree of economic development, aesthetic tastes and preferences. Social transformations, scientific and technological progress, lifestyle or way of life of a person, local historical and natural and climatic conditions, aesthetic ideal, peculiarities of the ethnic composition of the population - all these things in one way or another are reflected in an architectural form, which is understood in a broad sense - from urban complexes to individual buildings and their details.

The penetration and spread of the influence of the architecture of the neighboring countries on the territory of Great Volhynia will be understood, taking into account the close economic, political and cultural junction between Volhynia and Lithuania, the Czech

\footnotetext{
${ }^{*}$ Corresponding author: liliia.hnatiuk@npp.nau.edu.ua
} 
Republic and Poland. A large number of Volhynia magnates held high public positions in the Grand Duchy of Lithuania (lat. Magnus Ducatus Lithuaniae) and the Commonwealth of Poland, Polish-Lithuanian Commonwealth, and were certainly well aware of the advances in defense, architecture and construction applied in these countries [1]. And Prince Fedir Ostrozky, who fought on the side of the Hussites, was able to evaluate and borrow the basic elements of construction of the Czech Republic and Slovakia.

Also, the location between East and West determined the peculiarities of reflecting the liturgical and theological content, the canonical traditions in the structure and in the deep symbolic meaning of the temple.

Problems in the history of Christianity, the emergence and development of particular denominations in Ukraine have recently been at the forefront of scientific research and journalism.

According to some historians, Christian ideas penetrated into Volhynia in the second half of the IX century from Greater Moravia, where the enlightenment missionaries Cyril and Methodius acted. Some information about this period can be obtained from the Czech Chronicle of the Kuzma Prague, in which the territories of the Volhynia Region to the Styr River are listed as a part of the Prague Diocese founded by Cyril and Methodius [2].

In the early 80's of the X century Volhynia was a part of Kyivan Rus. In 968, according to the Story of the Past Years, Kyiv Prince Volodymyr Svyatoslavovych, after becoming a christian, sent his sons and priests to different lands of his country, in particular Vsevolod to Volhyn. In V.Tatischev's "Russian History" there is the following note: "Volodymyr went on the Dniester with two bishops, teaching, baptizing many people, and built the city in the land of Cherven named Volodymyr and created the Blessed Virgin Mary church, leaving the bishop Stepan there, and returned with joy." This message fully resonates with the message in the Nikon Chronicle. It is written in the Chronicle under № 992 that Kyiv Metropolitan Leon deployed Bishop Stefan to Volodymyr-Volhynsky. At the end of the $\mathrm{X}$ century Christianity was finally established in Volhynia.

All the Orthodox monasteries of the Volhynia Diocese were territorially distributed throughout the twelve counties of the former Volhynia province. In their development, the sacral complexes have undergone a rather difficult path of evolution. The first ones appeared in the times of the equally-apostolic prince Volodymyr (the 10th c.), their number increases in the XII-XIV cc. In the XVI century a new stage in the development of sacred construction started. Due to the acceptance of the Union, part of the Orthodox monasteries goes to the Union, others are closed and reopened after the accession of Volhynia to the Russian Empire [3, 4].

In the difficult times of Christianity, private individuals have taken up the task of arranging new sacral complexes. The case has been taken over either by entire fellowships or by strong (rich) Volhynia princes and nobles. Between them there are Families of Ostrozki, Czartoryski, Chetvertynski, Koretski, Sangushko, Hoyski, Kysyl, Malynowski, Drevynski, Puzyn, Iyelovytski, Bohovytonovski, Yarmolynski, Zagorovski and others [5$10]$.

Sacred complexes often include parish schools, for example, they were at the monasteries of the Krestozvizhensky Lutsk and Kremenetsky Epiphany monasteries, as well as at Goschansky and Volodymyrsky.

On the example of the sacred complexes of Volhynia we can also see the reflection of world architectural styles, which shows that culture and architecture developed not in isolation from neighboring countries, but in close interconnection [8, 11-13].

Sacred complexes of Volhynia have undergone a path of development, complicated by confessional changes, which affected their architectural image, influenced changes in the three-dimensional, spatial and planning structure. To solve the problems of restoration or 
reconstruction of sacred complexes it is necessary to trace the main stages of their historical development under the influence of historical, religious, political factors and national issues.

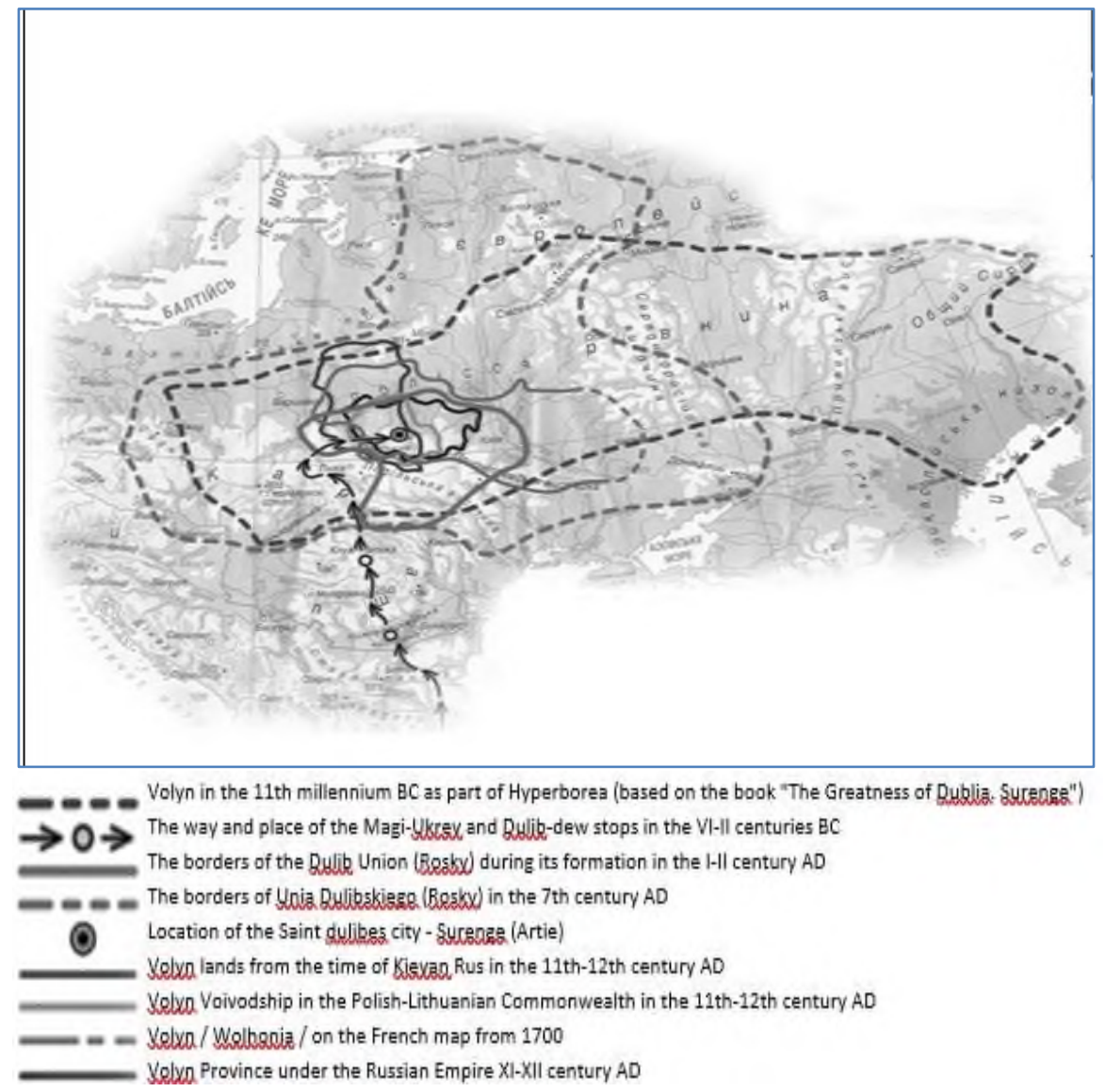

Fig. 1. The evolution of the boundaries of historical Volhynia.

One of the turning points in the formation of sacred complexes was the approval of the Union (1596). At the end of the XVII and early beginning of the XVIII centuries most of the monasteries in Volhynia joined the Union and were settled by monks of the Basilian Order $[12 ; 14]$ From the XVII century Volhynia monasteries, which did not accept the Union and remained on the traditional basis of official Orthodoxy, gradually for various reasons, got closed, abandoned, destroyed (the st.Nikolas Church in VolodymyrVolhynsky; the Church of the Holy Cross in Lutsk) [15]. At the same time, the number of Uniate and Catholic temples, which were built with regard to the canonical requirements of the new denominations, was noticeably increased (Christmas-Theotokos Church in KameiKashyrsky, Assumption Church in Zapruddi of Kamin-Kashirsky district). According to these requirements, some of the former Orthodox monasteries that had been converted to the Union (Zymnensky monastery, Pochaiv Lavra) were also overwhelmed $[11,16]$. The impoverished monasteries were transferred by the Uniates to parish churches and after accession of Volhynia to Russia (Fig. 1) in 1795 they remained without changes. [17-19].

After Volhynia's accession to the Russian Empire in the XIX century the reconstruction and restoration of abandoned Orthodox churches was done, projects of restructuring of Catholic churches in the Orthodox (Saint Trinity Cathedral - former Bernardine church in 
Lutsk, Assumption Church - the former church of the Augustinian in Radehiv village, Lyubomlsky district, etc.) were made [20].

Former Catholic monasteries were closed, and the churches were converted into parochial churches (the church in Berestechko is a former Trinitarian monastery). In order to converse the Czech and German colonists to the orthodoxy, new churches were erected in their settlements with additional state funding (Panteleimoniv Church in Lutsk) [19]. One of the characteristic features of the restructuring of religious buildings was the appearance of a bell tower: two or three tier with a tent cover (St. Nicholas Church in the Cherchytsy village; St. George Church in Lyuboml). New iconostases were being installed (Candlemass Church in Mykhnivtsi village, Kamin-Kashyrsky district). The rest of the changes were of a decorative nature and did not carry any structural load since they were made of wood and were mostly lost during the Second World War and as a result of numerous fires.

\section{Materials and methods}

\subsection{Period from the XI century - till the second half of the XIX century}

From the X to the XII centuries few sacred complexes in Volhynia are known. The number of them increased significantly in the XVI and XVIII centuries, at least since that time there has been more information about the Orthodox monasteries of Volhynia.

At the same time, there was increasing pressure on Catholicism by Orthodoxy.

The first Volhynia monasteries owe their appearance to the care of the great and distinguished princes of the Russ, for example, the equally apostolic prince Volodymyr, Danyil Romanovych, Lev Danylovych, Volodymyr Vasylkovych, Mstyslav Volodymyrovych and others.

The architects of antiquity perfectly possessed professional methods of construction of architectural form. Studies have noted that the ancient Russ sacral complexes are characterized by the proportionality of the parts and the whole connected by the system of decomposition, which are in a certain proportional relationship. A characteristic feature of the architectural and artistic expressiveness of the stone architecture of this period is the complete correspondence between the form of the structure and its structural and technical structure [21].

One of the oldest sacred complexes of Volhynia Diocese must be Zymnensky Church of the Cave Monastery, now village Zymno, near Volodymyr-Volhynsky. This is evidenced by the monastery church of the same masonry with the walls of the Volodymyr Cathedral, built in 1000. By the XIVth century 15 Orthodox monasteries had been founded. The number of sacral complexes was significantly increased in the XVI and XVIII centuries (Fig. 2.).

From the time of Kyivan Russ, Catholic penetration into Volhynia began. So, in 1075 Yaropolk Iziaslavovich, who ruled in Volhynia, made a treaty with the Pope Gregory VII, pledging to extend the influence of the Vatican to Russ.

Rome, the Roman popes tried to get from the Galician-Volhynia princes Roman Mstyslavovych and Danylo Romanovych support in the propagation of the Catholic faith, but at that time it did not produce significant results. The intensive penetration of Catholicism in Volhynia began at the end of the XIV century. In 1364 the Polish King Casimir the Great, having conquered Volodymyr-Volhynsky, founded a Catholic cathedral church here. In 1375, Pope Gregory XI established the Episcopal Chair in VolodymyrVolhynsky. In 1427 the Chair was moved to Lutsk. In 1390-93 Lutsk King Jagiello and Duke Vytautas founded the first Catholic Monastery of the Dominicans. At the end of the 
XV century the monastery of the same order was founded in Volodymyr-Volhynsky by the Polish King and Grand Duke of Lithuania Oleksander.

During the period when Volhynia was the part of the Grand Duchy of Lithuania, Catholic churches were built in a number of cities and villages, including VolodymyrVolhynky, Lutsk, Porytsk, Lyuboml, Perevaly, Ratne, and other cities and towns [5].

At the same time, many Orthodox monasteries either became desolate, for example, Kremenetsky Cathedral of Transfiguration, or passed to Union, for example, Zhydychynsky, Dorogobuzhsky and others which became the monasteries of the Basilian Order [12;14].

At the end of the first quarter of the XVIII century all the former Orthodox monasteries become Uniate. In Volhynia province there were at least thirty monasteries that had moved to Union during the XVIII century. At the same time, many monasteries, according to testimony of Metropolitan of Kyiv and Halych and all Russ Petro Mohyla, were desolated and destroyed.

In 1744, the Uniate clergy decided to demolish and liquidate the small Basilian monasteries that had become desolate [Pochaiv, archival file of 1744, No. 376].

By virtue of this decree, the impoverished (insolvent) Uniate monasteries were gradually destroyed, and their property and monks were attributed to others. So Chetvertynsky, Kolodiazhenskyy monasteries were attributed in such a way and Zymnensky and Nyzkynytsky monasteries were impoverished and fell into debt [22].

Catholicism was widespread after the Union of Lublin in 1565, when Volhynia became a part of the Polish kingdom. There were many Catholic monasteries in the region [23]. In 1606, the Jesuits established a monastery in Lutsk and opened a school there. In 1755, the monastery of the same order was founded in Volodymyr-Volhynsky by Ratnaya monitor Ignatius Sadovsky (Fig. 2). Under the influence of the Jesuits, much of the Volhynia nobility was converted to Catholicism, the Order did a lot to spread the Union to the land. In 1773, Pope Clement XIV dissolved the Order and ceased its activities in Volhynia.

At the end of the XVI century the activity of barefoot Carmelites in Volhynia was also spreading. Members of the Order led a solitary lifestyle, were fed by alms. In 1679, Prince Mykola Sapiga founded the Carmelite Monastery in Dorohostay. In 1691, male, and in 1720, female Carmelite monasteries were founded in Kysylyn. In 1740, the Order's monastery existed in Lutsk, and since 1750 in the village of Stobykhov. Around 1639, a monastery of the Carmelite Order was founded in Chartoryisk by Andriy Leshchynsky to bury his Catholic wife. The monastery of the same order was founded in 1771 in the village of Vyshenky near Lutsk by Dominik Manevytsky. Monasteries of other Catholic orders were also founded: the Capuchins in Volodymyr-Volhynsky, the Collegiates in Olytsa, the Franciscans in Dorohobuzh, the Trinitarians in Berestechko, the Piarist in Lyubeshiv and others. At the same time, Catholic churches were built and refurbished in many cities and villages in Volhynia [24].

Thus, the ancient Russ shrine namely Assumption Cathedral in Volodymyr-Volhynsky, which after the Brest Union in 1595 became the Uniate cathedral, during the XVIIXVIII centuries after a few adjustments became unrecognizable. Two octagonal bell towers were symmetrically annexed to the western facade of the temple, and between them there was a portico completed with a pediment [21].

A monastery church of St. Michael the Archangel in the village Bilostok experienced such alterations but in a smaller volume at the time when the monastery was Uniate (1736 1796). In order to give the church a "catholic" appearance, the western part of the temple was added. A Trinity Church of the Monastery in the village Mezhyrich from 1612 became the church of the Franciscan monastery [25]. The Zymnensky Svyatogirsky Monastery was rebuilt - three domes (middle and two eastern corner ones) were removed from the main 
Assumption Church, and only two pediments were left in order "the Orthodox Church to resemble the Latin one" [22].

In the Uniate monasteries catalog (Katalogus monasteriorum ordinis S.B. Pochaev 1775 year) the following Uniate monasteries of Volodymyrska Province are listed: Bilystotsky, Kremenetsky, Horodyshchynsky, Goshchansky, Lubarsky, Lutsky, Mylchansky, Meletsky, Nyzkynytsky, Ovrutsky, Pochaivsky, Piddubetsky, Straklivsky, Tryhirsky, Tumynsky, Zahayetsky, Zagorovsky, Zymnensky and Zlochevsky. Some complexes are not included in this list. From other sources it is known about the existence of other Uniate monasteries at this time, namely Zhydychynsky, Dorohobuzhsky and others [26].

After the annexation of Volhynia to the Russian Empire (1795), favorable conditions for the spread of Catholicism in Volhynia were put to an end. Gradually, the Catholic churches and monasteries were closed or converted, the characteristic features of these structures were actively and purposefully destroyed, and the Uniate churches were rebuilt into Orthodox ones.

Also in the first half of the XVI century reformed communities of Anabaptists, Calvinists and Antitrinetrians operated. In the 70's of the XVI century in Volhynia the reformist views were actively promoted by the nobleman Kodiyan Chaplych, who gave shelter to the Russian heretics Theodosius Kosy and Ignatius, whose views were consonant with the views of the reformers. The Reformation had a great influence in Volhynia, in particular, it was reflected in the activities of Lutsk Holy Cross Brotherhood. The brothers, like the Reformers, focused on internal religiosity and upheld the principle of equality between the clergy and the laity in the solution of church matters. Calvinism as one of the most common courses of the Reformation among the gentry of the Commonwealth in the 2nd part of XV-XVIII centuries did not become widespread in Volhynia. The largest Calvinist community, founded around 1585 by Prince Alexander Pronsky, existed in Berestechko [1], after his death Andrei Leshchynsky became the patron of the community. In 1639 a synod of Calvinists was held in Berestechko. From 1595 to 1643 there was a community of Calvinists in the Dorohostay village [10].

Volhynia in the XVI century became one of the centers of anti-Trinitarianism in the Commonwealth: in Volhynia many communities functioned at the court of Konstantyn Ostrozky; in Berestechko (mentioned in 1643 ), Bereisk (mentioned in 1641), Dovzh (1646-53; in 1646; 1648; 1651; 1652 - synods of anti-Trinitarians); Halychany (163; 169$50 ; 1653)$; Ivanychi $(1643 ; 1648-50 ; 1652 ; 1653)$; Kyselyn $(1612-45$, in 1638; 1639; 1640 synods in Kamin-Kashyrsky, maybe in Vodyrady village as well (now Oderady village). In Volhynia in the 40s of the XVII century a well-known antitrinitarizm ideologue Andrii Vynovatyi lived.

In the 30's of the XVI century in Volhynia, in particular, in Volodymyr-Volhynsky there were groups of Anabaptists, who felt strongly negative about the feudal system, demanded a second baptism in adulthood to create a free church that would not recognize state interference in their affairs. The influence of the above-mentioned communities wasn't significantly reflected in the architectural and spatial structure of the Volhynia temple.

On May 26, 1794, on the occasion of the annexation of Volhynia to Russia, Archbishop of Minsk and Volhynia Victor proclaimed an appesl "To the torn away children of the church" about reunification with it. In virtue of this appeal, with the assistance of civil (secular) leadership, many of the monasteries were either returned to the Orthodox Church or were "secularized". Nevertheless, in the early XIX century more than 10 monasteries remained Uniate. Chatsky's educational plans gave them new meaning.

Activities of Catholic centers in the period from the end of XVI to the end of XVIII century contributed to the Catholicization and partially to polarization of the Ukrainian nobility. But in the early 30's of the XIX century in response to the Polish 
uprising many churches and monasteries were closed and temples were placed at the disposal of the Orthodox clergy [27].

In the middle of the XIX century a large amount of public money was spent on the conversion of churches to Orthodox churches (including the arrangement of iconostasis, the completion of belfries, the completion of bell towers). The main motives for state funding for the construction of Orthodox temples are the conversion of the Czech and German colonists to the Orthodox faith (Fig. 2).

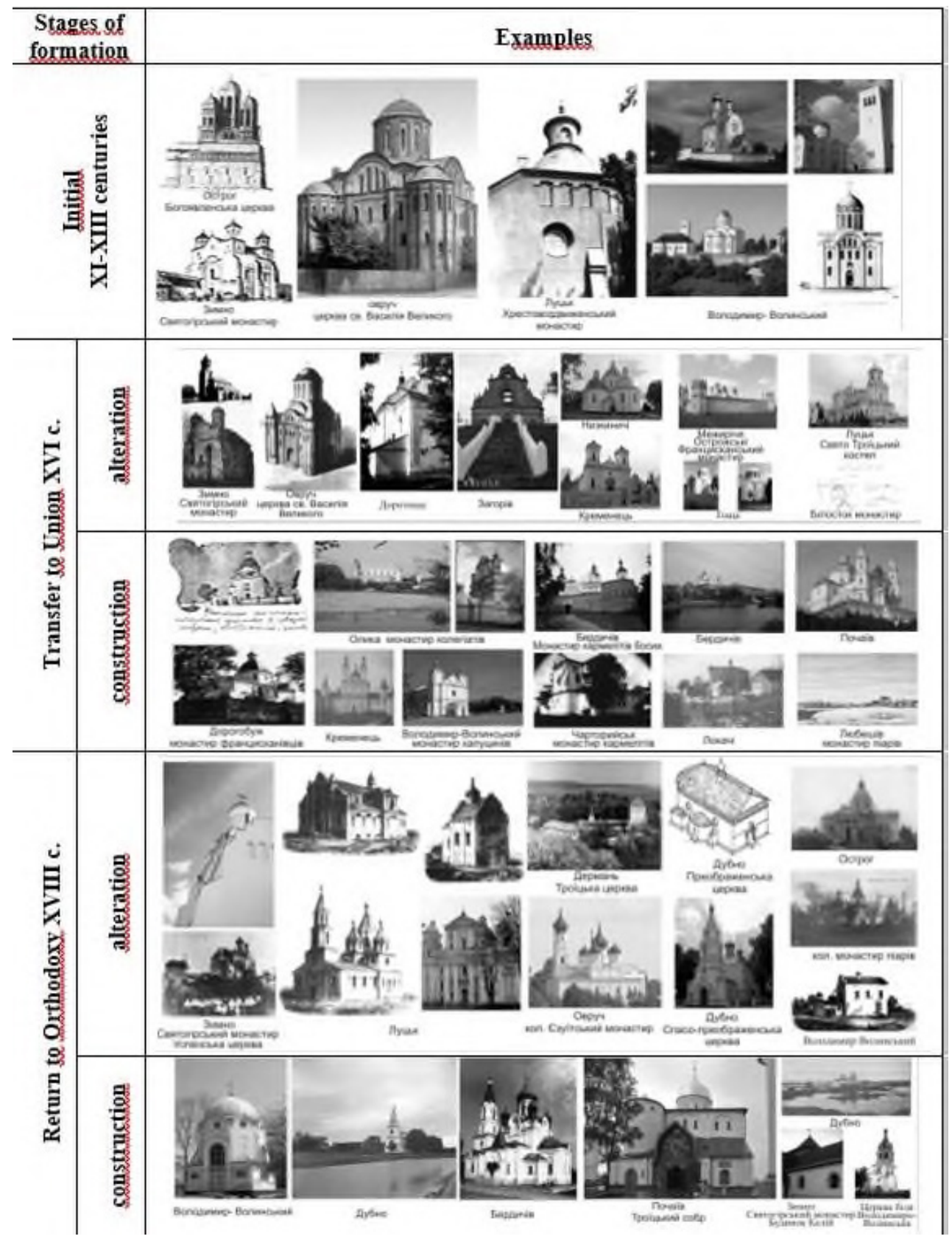

Fig. 2. Differentiation of the formation of sacral complexes depending on the confessional affiliation. 
Second half of the XIX century (the time of total return to Orthodoxy) was the period of restoration, restructuring, reconstruction and construction of new temples [10]. As a result, the monuments acquired new features, characteristic of the dominant direction in the Russian cult architecture of that time [27]. On the facades of many Volhynia temples of the XVIII-XVIII centuries (Zymno, Lyuboml, Pochayev, etc.), details, characteristic of architectural forms of classicism appeared: triangular pediments, profiles of eaves were changed, pilasters and entablature were glued. Completions in the form of a bow-shaped dome that dominates the structure, pedestals at the apexes of the roof and other decorative details that were structurally inappropriate to the structure of the Volhynia temple appeared [26]. Thus, in the 1840's, the appearance of the Trinity Church in Derman, which is now perceived as a mid- XIX - century building, changed dramatically [1].

Characteristic architectural features were lost as a result of remodeling in the first half of the XIX century in the architectural and volumetric image of the Transfiguration Church in Dubno: the western part of the church was completed; the decor elements of the Volhynia architectural school of the XVI-XVII centuries were destroyed. Classicistic decor in the form of a complex composition with pilasters adorned the facades of the Christmas church in Clevan; a frieze decorated with triglyphs appeared on the facades of the Mykolaiv Monastery Church in the village Myltsi [22].

In 1891-1899 the reconstruction of the Assumption Church of Sviatogirsky Monastery in Zymno was also carried out, as a result the original features of its architecture were destroyed. Instead of two dismantled corner defense towers over the western part of the temple, three tops with onion-shaped domes were built; the central one was much larger than the lateral ones. On the windows a lush frame with "kokoshnyk" appeared, a new eave completed the walls of the temple. All these changes are structurally unjustified and bear only a decorative load.

A vestibule was built in many churches to the west in the late XIX century, and in almost every cult ensemble there was a bell tower, which was usually located to the west of the church, relatively to its central axis. Covering was a tent (four- and octagonal) finished with a dome. The composition and decoration of the bell tower were related to the pseudo Russian style [28].

In 1807, under the influence of Chatsky, orders were made to arrange county and parish schools at all Basilian monasteries (Pochaiv, archive file 1794 year No. 983). As a result, all Basilic monasteries had county and parish schools, redeveloped or formerly converted ones. The order of study in these schools can be determined by one of the reports of the Lubar county school.

The education concentrated in the Basilian monasteries was the reason that the former Basilians of the Volhynia region are still remembered as educated people.I

n 1839, all Basilian monasteries were either abolished or transferred to the Orthodox clergy. At the end of the XIX century there were no Catholic monasteries at the territory of the modern Volhynia region $[12 ; 14]$.

In the second half of the XIX century there were eleven Orthodox monasteries, namely Pochayiv Lavra Monastery and assigned to Lavra Dubno Khrestozdvyzhensky monastery, Dermansky monastery, Lypetsky Zagorovsky monastery, Volodymyrsky Khrestozdvyzhensky monastery, Kremenetsky monastery (former Zahayetsky monastery), Lubarsky monastery, Tryhirsky monastery and nunneries - Koretsky and Horodyshchensky.

Theological and liturgical content are directly reflected in the figurative structure of the temple [29].

In the formal aspect, which is directly related to the substantive, immutability (canonicity) supported by tradition (testimony, revelation of the Gospel), is decisive. The immutability of forms is often associated with archaicism, backwardness, timelessness, but the problem is much deeper. The immutability of the forms implies their perfection, time- 
tested, like ideality (no need for change), and the main tenet in this matter lies in the inseparability of form and content, which is inherent in this form, this formal solution, not any other. This is syncretism - formal and substantive inseparability.

Attempts of separation lead to destruction of such integrity, the loss of its essence. Such historically created semantic formalities are signs, symbols, images, archetypes that are embedded in the minds of generations of people and are perceived uniquely, constituting a certain expressive language used by different peoples, different generations and different traditions.

Consecrated by time, tradition, accepted by people such integrity acquires sanctified immutability that is not discussed within the tradition. The meaning of the canon is not so aesthetic, but above all semantic. The canon is a means of transmitting a signal, a message, a way of communication which is not invented, imaginary but real. The aesthetic function in the canon - both essential and communicative, the beauty of the symbol, sign, canon - is a compulsory testimony of their perfection, maturity - conditions of acceptance of both sides of communication: the signified and its perception [27].

The tendency of the liturgical restoration, which leads to rethinking of the spatial foundation of the temple, is also accompanied by the intensification of conservative tendencies, according to which a kind of "temple style" made in classical forms of the past eras was considered inviolable and worthy of unconditional application [7].

Instead, the minimization of plastic expressive means leads not only to the visual but also to the imaging (in theological sense) impoverishment of the space and environment of the temple, and complicates the perception and understanding of the liturgy.

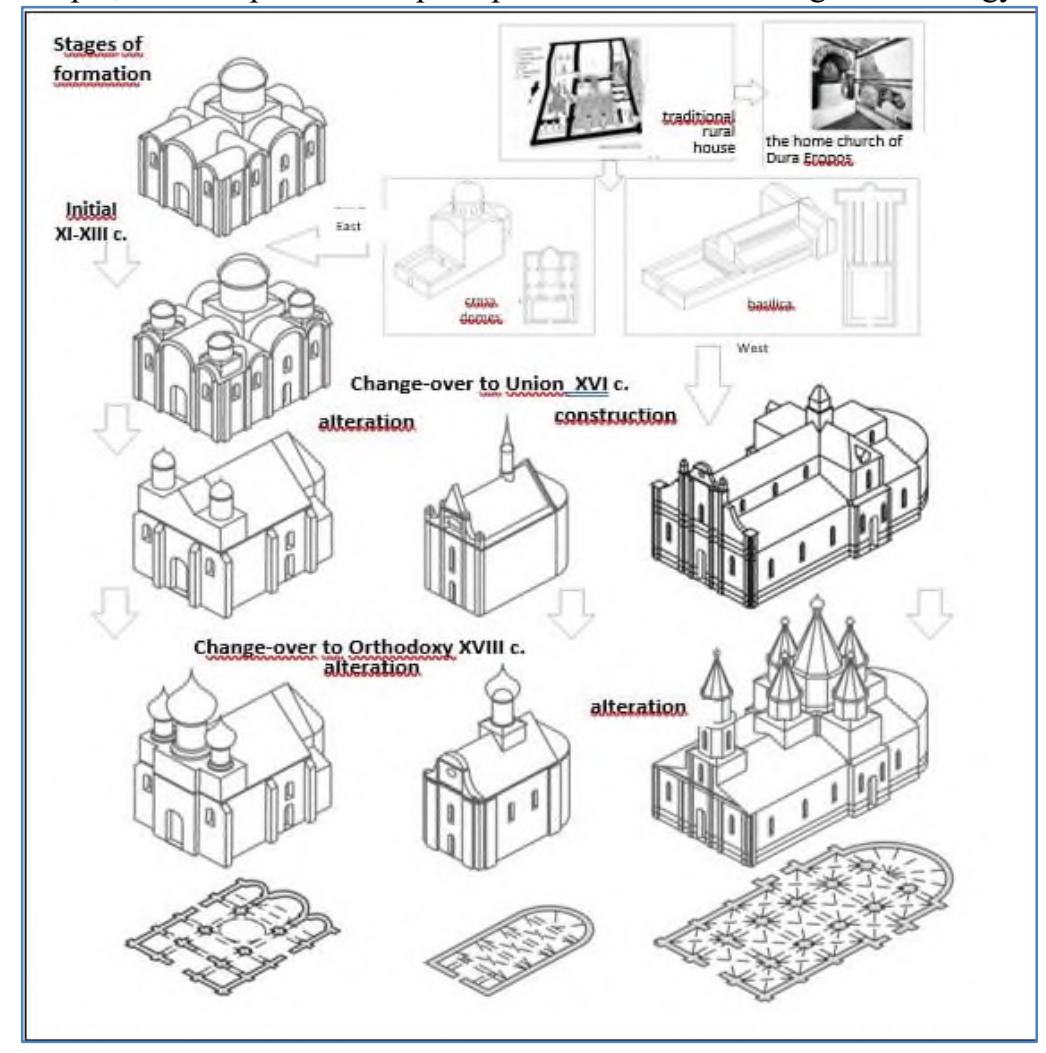

Fig. 3. Change of form and image depending on the change of confessional affiliation. 
To some extent Catholic activity was revived at the time when Volhynia was a part of Poland in 1921-1939. After the Second World War, Catholic communities ceased their activities in the country. In 1990, the Catholic community was registered in Lutsk. After that, community registration began in other cities and towns of Volhynia.

Today communities of different denominations coexist in almost every town: Catholic, Greek Catholic, and Orthodox. From the 90s of the XX century a new phase of Christianity in Volhynia began.

Temples and monasteries were returned, but not always the restoration and renewal of sacred complexes were preceded by exhaustive pre-project studies, which in turn led to a distortion of their image (Fig. 3).

\subsection{Period from XX till XXI centuries. Nowadays}

Sacred architecture of the XX century was characterized by an unprecedented variety of artistic formulas in the world. The reason for this was the emergence of new theological ideas and artistic concepts at the turn of the XIX-XX centuries, which contradicted more traditional approaches. One of the important ideological phenomena that violated the existing foundations of church construction was the theology of the theologians about the positive meaning of the phenomenon of desacralization. This view allowed the rejection of the difference between the spheres of being sacred and secular, and in architecture led to the existence of two mutually exclusive customs: preserving the traditional character of one and accepting everything extraordinary from the other. More contradictory concepts existed that violated the homogeneity of sacred objects characteristic of earlier eras, which included attitudes to beauty and symbol, changes in liturgy, and the possibility of using architectural modernism to create places of worship. Some architects supported the canonical values of ancient religious architecture, while a growing number of other artists tried to apply radically new forms. Over the years, logic and consistency in both groups began to weaken, and the contradictions between "traditionalists" and "modernists" lost clarity [7].

At the same time, the XX century for Ukraine is a period of total halt of construction of any new temples. The end of the XX - the beginning of the XXI century is the period of restoration of temple building on the territory of Ukraine in traditional forms with observance of all canons and rules. At the same time, the method of idealization of the type, established and repeated in the formation of the artistic image of the sacral space, invariably coexisted with a breakthrough beyond the limits of conservatism [29-33].

The revival of religious construction after the declaration of independence was faster where more temple buildings were physically preserved, that is, in Western Ukrainian lands. This is primarily due to the fact that the Soviet authorities finally came to Western Ukraine 30 years later (in 1939) than to the rest of the territory, which helped to avoid the fatal repression and destruction for the religion and shrines of the 20-30s of the XX century. The ideas of church renaissance was spread throughout Ukraine from Western Ukraine.

The pace of temple construction in the 1990s is astounding. During the first ten years of Ukrainian independence over nine thousand temples were designed and built in the country, that is, we had a boom in church construction [34, 35].

Due to a long break in the construction of churches, this type of structure did not actually develop, so modern architects are forced to revive and re-invent the principles of temple construction. An inexhaustible and unique source of up-to-date creativity is historical heritage. In addition, the continuation of traditionalist tendencies is in line with the tradition of the Ukrainian Eastern Church. The main architectural periods for imitation in Ukrainian sacral architecture today are the following: the period of Kyivan Russ, the Baroque period and the end of the XIX - the first third of the XX century. The sacral architecture of these periods is the source for style searches in modern temple building. 
Architects use the historical heritage of church construction in different ways. In modern project practice the following methods of creativity are distinguished: historical stylization (or direct reproduction), free interpretation and modernization.

The stylistic development of modern sacral architecture in Ukraine is characterized by two parallel trends: historicism and the search for new forms. The notion of historicism terminologically introduces modern sacral architecture of Ukraine into the postmodern space. Historicism thus acts in the form of traditionalism, an appeal to the established norms and canons of design. As a creative method, historicism involves the use of examples of historical architectural heritage and their use in current creativity.

In contemporary design practice, architects use a variety of creative design methods that are based on the use of historical heritage. The first of these methods is direct reproduction, accurate historical stylization of the structure. The use of this method requires a thorough knowledge of historical models, the free mastery of the principles of styling. So often this method is used by the architects, who came to sacred building from the profession of restorer. Direct reproduction involves both the reconstruction of structures that have been destroyed for one reason or another, and the construction of new objects with the exact requirements and canons chosen for the design style, the exact reproduction of architectural details and motifs. Unfortunately, examples of new construction on the territory of historical Volhynia often distort historical style without creating interesting artistic image.

The tendencies of modern Ukrainian temple building are based on three distinct "points of appeal" for their development: princely architecture (X-XIV centuries), Ukrainian Baroque shrines (XVI - XVIII centuries) and examples of Ukrainian style of the late XIX early XX century, which continued the traditions of the Byzantine school. A characteristic feature of each of these epochs is not only that they were periods of the greatest heyday of Ukrainian architecture, but also that each of them was not completed historically, that is, did not pass from one artistic system to another, but was suddenly stopped by public cataclysms. Nostalgia for the unfinished and the unproven has become the main lever that drives the modern church architecture of Ukraine.

As examples of use of forms of princely architecture we can consider some temples of Rivne and Volhynia regions (Fig. 6, 10-11).

Baroque is one of the most striking pages of the architectural heritage of the Ukrainian people, which is associated with a period of relative independence of Ukraine, a period of heroic struggle and active construction activity [36]. Baroque architecture is one of the favorite themes for the latest architectural experiments in the field of sacred construction. The peculiar interpretation of the development of Baroque themes are the churches represented in Fig. 15-16.

Ukrainian style in the sacral construction of the late XIX - early XX centuries is presented primarily by neo-Byzantineism, the largest number of specimens of which were preserved in the Western Ukraine. Neo-Byzantine principles are widely used in projects by churches of different denominations: these are temples in Figs. 4, 7. Unfortunately a large number of churches is still built in pseudo-Moscow style (Fig. 9, 12, 13), the ruins of the old abandoned Catholic temples are also used(Fig. 8). Sometimes it is just a pure functional option for the needs of believers without conceptual development of any artistic image (Fig. 5).

However, some architects choose a different creative method in design - a free interpretation of the architectural prototype, which may be more or less close to the accuracy of copy to the original, but allows the reduction of architectural motifs and details, change their scale and role in the structure of the object, while architectural source must be easy to identify. An example of such a method of contemporary temple-building is shown in Fig. 17. 
Another method of creativity that Ukrainian architects rarely resort to is modernization of traditional architectural forms. The basis of the method is the "extraction" of certain symbols, signs, archetypes associated with a particular style from an established architectural system. There are few examples of modernization due to the conservative thinking of the clients (church communities) on the one hand, and the unwillingness of many architects to use ultra-modern forms in sacred construction on the other hand. Most of them remain unrealized projects.

The search for the latest architectural forms and departure from tradition in its formal solution is the result of the desire of architects to introduce modern sacred architecture of Ukraine in the European orbit of temple building [7]. Implementing new ideas is difficult, many of them remain at the project level, as customer communities prefer to have traditional buildings. However, it should be noted that a complete departure from tradition in church building is impossible, as new themes are developed on the basis of the same architectural prototypes mentioned above. When creating new images and searching for new languages, architects are based on the traditions and canonical requirements of church architecture.

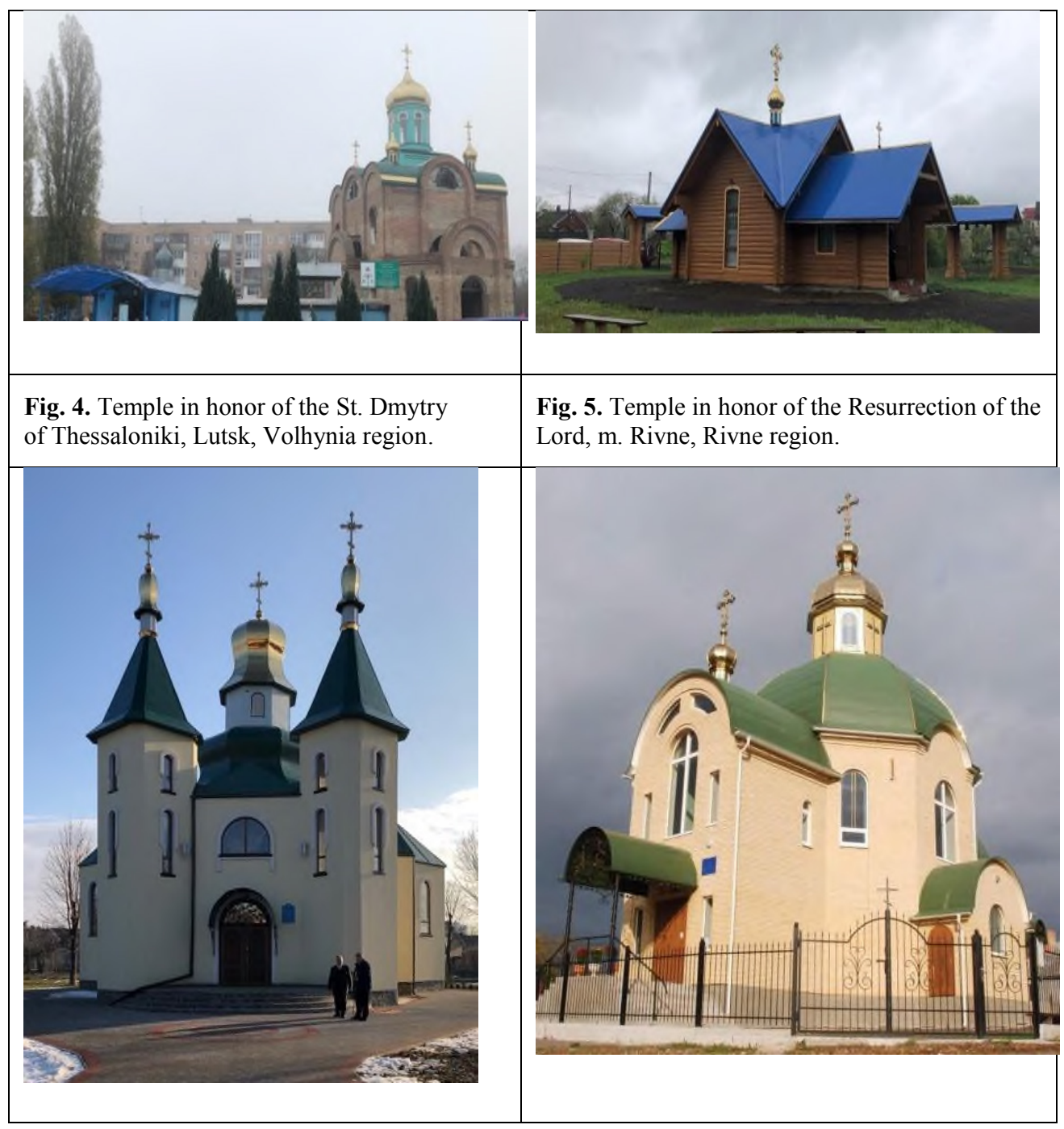


Fig. 6. Temple in honor of apostles Peter and Paul in Lutsk, Volhynia region.
Fig. 7. Temple in honor of the Holy

Spirit, Velyky Omelianyk village, Lutsk district, Volhynia region.
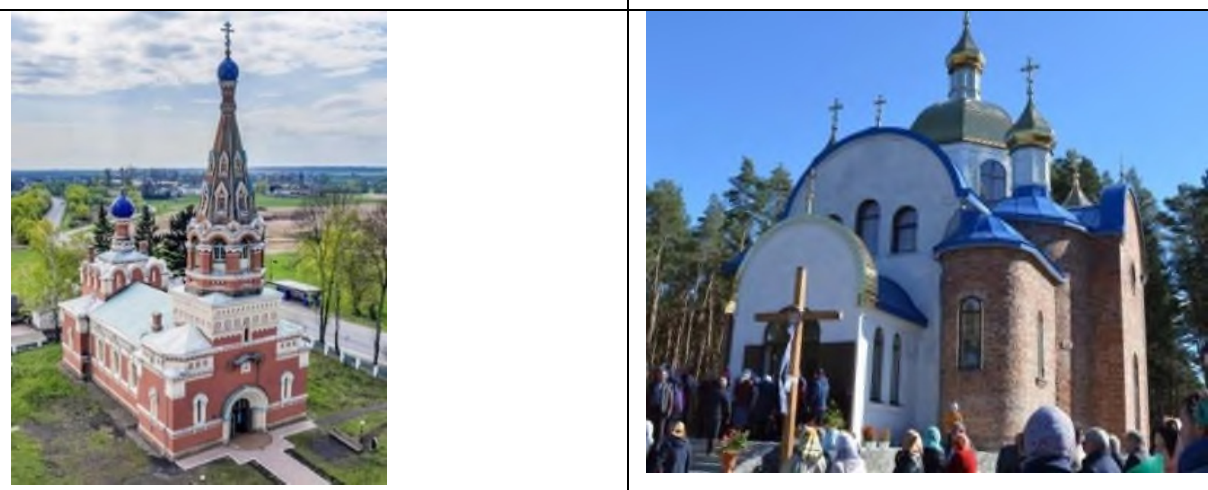

Fig. 8. St. Dmitry Temple, Zhuravnyky village, Horokhiv district, Volhynia.
Fig. 9. Church of Vira, Nadiya and liubov and their mother Sophia, Manevychi village,

Volhynia.

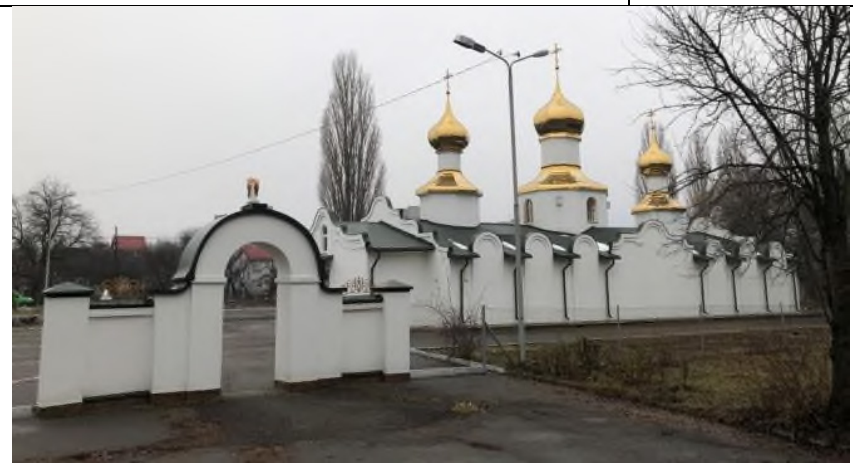

Fig. 9. Temple of the St. Dmitry from Thessalonic, Lutsk, Volhynia region.
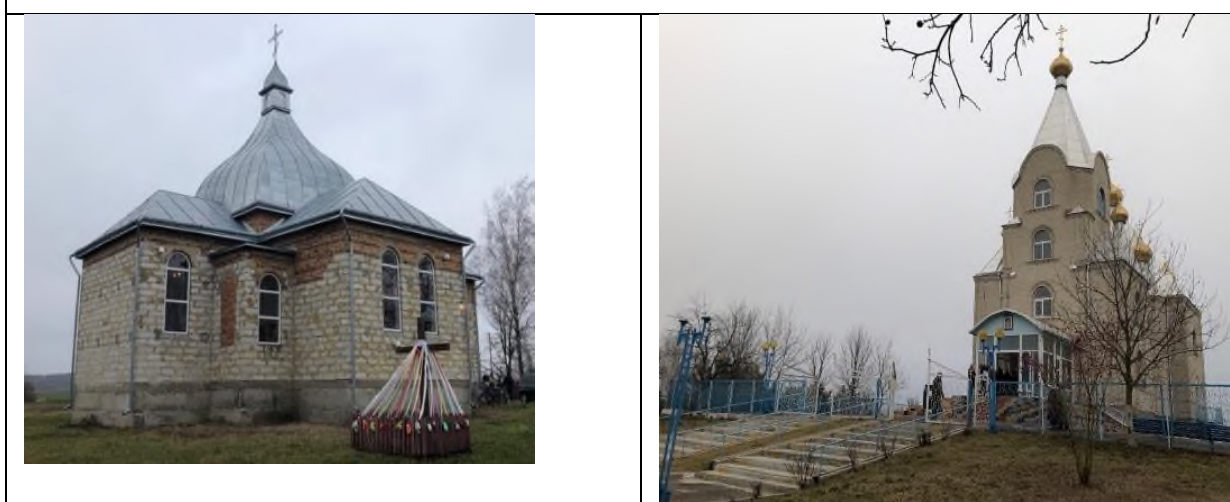
Fig. 10. Temple of the Archangel Michael, Novy Dvir village, Turiy district, Volhynia region.

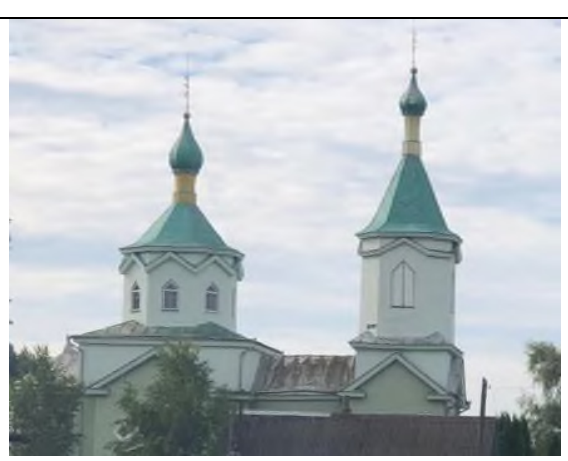

Fig. 12. Church of the Nativity of the Blessed Virgin Mary, Korablysche village, Mlyniv district, Rivne region.
Fig. 11. Church of the Nativity of the Blessed Virgin Mary, Buyany village, Lutsk district, Volhynia region.

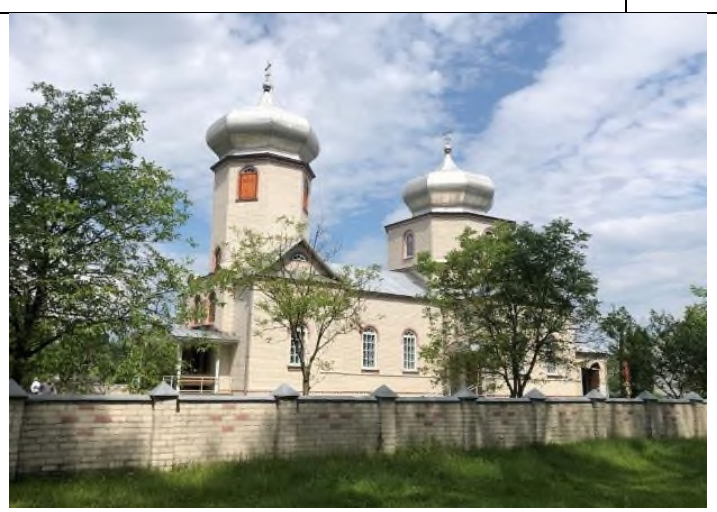

Fig. 13. Temple of the Intercession of the Blessed Virgin, Vladyslavivka village, Mlyniv district, Rivne region.

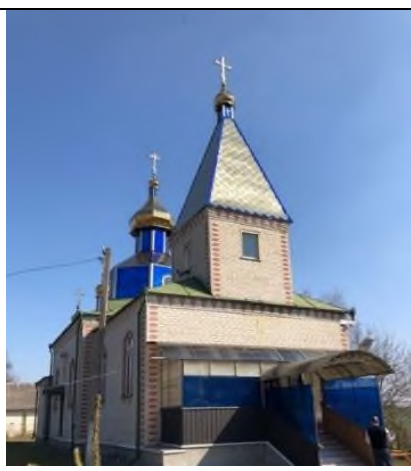

Fig. 14. Temple of St. Jow of Pochaiv, Smyga town, Dubensky district, Rivne region.
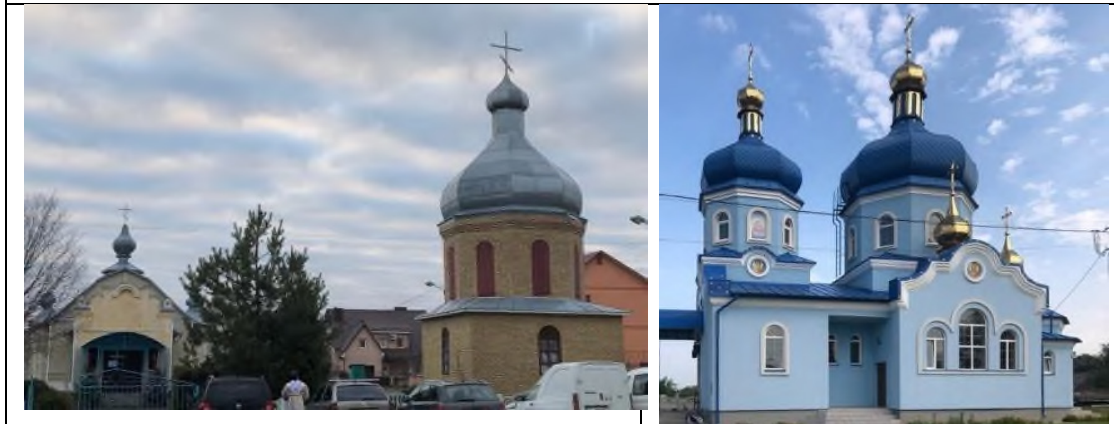

Fig. 15. Temple of the St. Yuri, Kostopil city,

Fig. 16. Church of the Nativity of the Blessed 


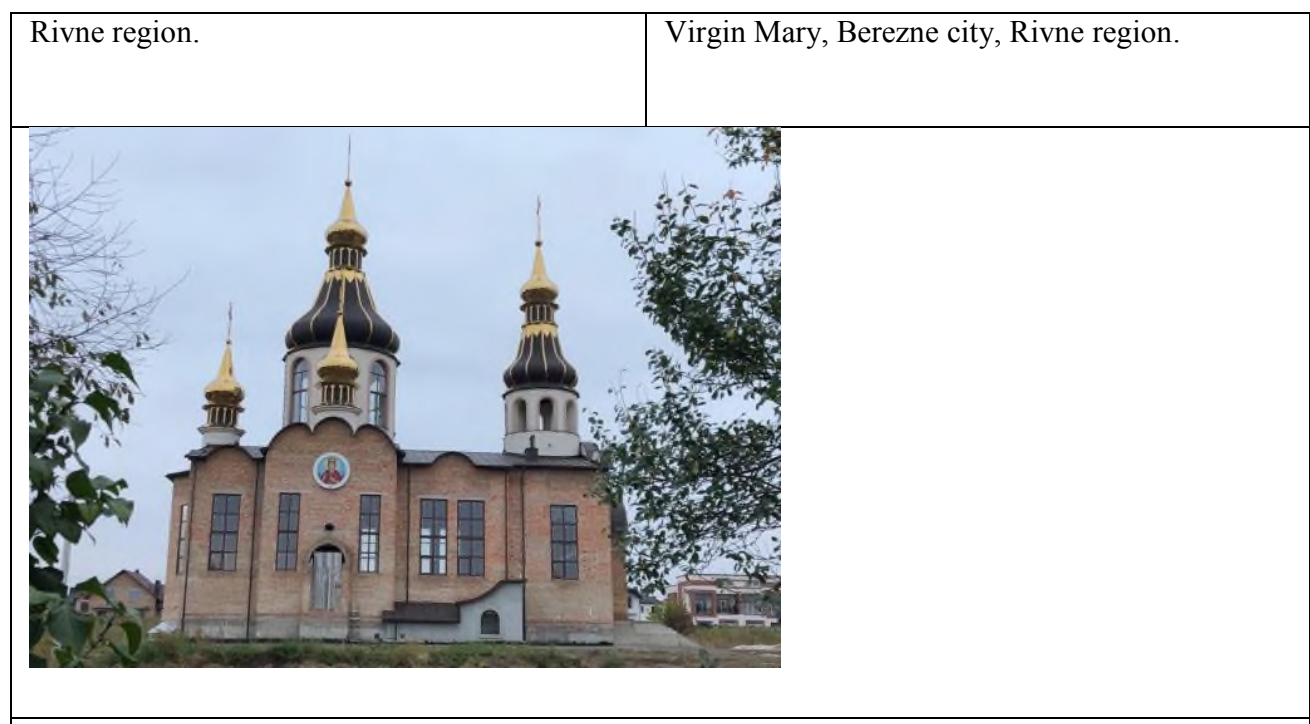

Fig. 17. Cathedral of the Lord Ascension, Rivne, Rivne region.

It should be noted that tradition is one of the most important components and means of creation and progress in the development of church architecture. Thanks to it, on a historical and national basis, we can see ways of creating expressions of national peculiarities and features that appear in the architecture of church buildings on certain grounds and meanings. As a matter of fact, through them the temple building have certain outlined features and forms of its identification and integration in the formed spatial environment and in a certain shaping structure [37].

At the same time, innovations in the church architecture of Ukraine, despite certain canonical, figurative, symbolic and hierarchical foundations, are a significant driver in the search for spatial-planning solutions. In general, it is, in fact, a modern approach to expressing ideas, forms, and materials and, of course, architectural and design solutions and searches. It is also manifested in the fundamental features and principles of the formation, layout and architectural and spatial structure, as well as the formation of the environment the place of manifestation of the entire sacral essence in the temple building. Among the concepts of identity [38] known in science, national identity remains one of the most important and complete, because what is understood as national identity encompasses both culture and ethnic and political identity, which are inherent in both the political and cultural communities.

Analyzing the modern achievements of Ukrainian architects in the field of temple construction, we can outline three main trends in the architectural and compositional solution of temple structures. They are:

- tendency to actively use established traditions;

- tendency of retrospective reminiscences;

- tendency of innovative searches.

The tendency to actively use established traditions has a wide range. This is a citation of forms, individual elements of a particular historical style, or a combination of different style replicas. It is the creation of temples with distinctive associative features of images of famous monuments of cult architecture and direct application of traditional architecturalspatial and structural schemes or styles of the past. As a rule, the styles that are typical for the periods of the widest development of cultural, artistic and architectural thought in the 
territory of Ukraine are usually taken as the basis - Kyiv Russ, Baroque, and the style of Ukrainian modernity.

The tendency of retrospective reminiscences is characterized by the appeal to the abovementioned styles; however, it has new features of the artistic expressiveness of the temples. By creative rethinking of the stylistic forms of the past, distinguishing original, autochthonous motifs and signs from them architects are trying to invent updated signs of contemporary temple formation.

The tendency of innovative searches is aimed at inventing a new volume- compositional image of the temple and has great potential for the further development of church architecture. It is based, according to architect R. Zhuk, "... on more abstract concepts such as rhythm, proportion, scale, determining the relation of space, mass and plane," and on the associative use of the characteristic features of the traditional semantics of temples. Successful examples of such an architectural tendency may testify to the emergence of a new imagery, for as we know, the most remarkable monuments of different historical styles at the time of their origin were marked by extremely brave and unconventional architectural and compositional solutions and semantic originality of sign forms. This tendency is inherent in the temple architecture of the West of Ukraine, where there is a significant influence of innovative ideas prevailing in the religious life of the Roman and Greek Catholic churches.

At the same time, new tendencies are not only renewal and enrichment, overcoming inertia, inhibiting actions of the past, but also the birth of new modern traditions in the dialectic of their progressive development. It's undoubted that the set of historical stages of development of Ukrainian sacred architecture has created a rich foundation with a variety of forms and images, three-dimensional solutions, polished and tested over the centuries, on which modern architecture of temple buildings is based, draws vital forces and continues to create in continuous progress to the future. Thus, the main pattern of development of Ukrainian temple building is the historical and cultural continuity of established traditions of national architecture, which should be further embodied taking into account the new times and the latest trends in domestic and world experience of temple construction.

Today it's necessary to restore the sacred understanding of temple building as the embodiment of the Idea, not the image. Architecture, especially sacred one, must be an expression of time, place and destination. In spite of the widespread tendency to copy the historical forms of temples, the attempts to translate the sacred idea into contemporary architectural forms of interpretation are of particular interest. At the same time, formation is not possible only for the sake of finding a new form, but in connection with tradition, transmission, and canons without interrupting. Sometimes the form violates the sacred meaning of space, and although it is a specific type of buildings, but in it, based on historical experience, given the geographical features and dynamism of modernity, you can and should strive for individuality. But first of all, it is necessary to realize that the temple is not just a building, but a HOUSE, a creation of man, which should serve the Creator, be a place of communion with God. The house must be alive, and a person breathes heat into it, and the architect creates only space....

\section{Conclusions}

This study offers a historiographical examination of the genesis of sacral complexes as a system in a system - a complex system of interconnected structures in an even more complex system of urban, historical and political entities.

1. The genesis of the architectural and spatial structure of buildings in general, and of sacral complexes in particular, is an important factor in the construction of new sacral complexes and in carrying out restoration works. That is why historical aspects are 
extremely important in analyzing both the theoretical foundations of the formation, urban development complexes in general and particular structures in particular.

2. Based on the research, it can be concluded that sacral objects are one of the most common types of public buildings in construction, and sacral architecture was characterized by an unprecedented variety of artistic formulas. So:

3. Features of the sacred essence, canonical traditions of temple construction and symbolism of its architectural forms are revealed through the basic provisions of theological understanding of the phenomenon of sacred space, taking into account the differentiation of perception of the temple by the recipient, architect and priest. The architecture of the temple, in terms of form and content, must correspond to the basic idea of the universality of the Christian church, to be a perfect image of the world.

4. The reflection of theological and liturgical content in the figurative structure of the temple is directly related to the meaningful embodiment of the defining immutability based on tradition. Historically composed semantic-formal integrations are signs, symbols, images, archetypes, which are embedded in the minds of generations of people and perceived by them unambiguously, constitute a certain expressive language used by different peoples, different generations and different traditions.

5. The Church considered itrself entitled to be a judge of the arts, choosing from works of art those which corresponded to faith, piety, and law. The Church paid special attention to the fact that works of art, fulfilling their functional purpose, serve with dignity the manifestation of religiosity (worship), while accepting the changes in material, form and decor, decoration, which eventually arose due to the development of technology.

6. To understand sacred art, it is important to understand the liturgy itself, which, being a supernatural reality, is expressed through signs, although it is neither a sign nor a symbol. True sacred art makes the liturgy visible through the means of expression, increasing its value to man. Awareness of this directly affects the architecture, which, introduced to rituals and worship (ceremonies, words, poetry, carving, painting), actively affects the inner world of man. Sacred art is sacramental or even saint art, which is designed to form the space of the temple and serve the sacred ordinances. Art develops through the search and discovery of form.

7. The sacred architecture of Volhynia in its forms clearly reflects the political and ideological views of the society of the relevant historical conditions. The genesis of the sacral complexes occurred in connection with state-forming, religious, social and social processes. In times of Christianity placing of sacred complexes was done by individuals as whole fraternity or strong (rich) princes and tycoons of Volhynia, among them we can meet the families of Ostrozki, Czartoryski, Chetvertynski, Koretski, Sangushko, Hoyski, Kysyli, Malynovski, Drevynski, Puzyn, Yelovytski, Bogovytonov, Yarmolynski, Zahorovski and others. This was reflected in the choice of the main activity of the sacred complex and, accordingly, in the image of the temple.

8. The location between east and west, both in the geopolitical and denominational context, determined the peculiarities of reflecting the liturgical and theological content, the canonical traditions in the structure and in the deep symbolic meaning of the temple. The changes in the image of monastery complexes in connection with the transition to Union (XVI-XVIII centuries) and with the return to Orthodoxy (XIX century), which completely corresponded to changes in confessional affiliation were significant. Constructive elements were changed: the central dome was replaced by a signature, and the western ones by towers, and vice versa. The rest of the changes were decorative (window framing, portals, etc.) and did not carry any structural load since they were made of wood and were largely lost during the Second World War and as a result of numerous fires.

\section{Referenses}


1. Archive of South-Western Russia, published by the Provisional Commission for the analysis of ancient acts established under the Kiev Military, Podolsky and Volyn governor-general, Acts related to the history of the Orthodox Church in South-West Russia, 1 (1), 555 (1859), Acts on church-religious relations in South-Western Russia (1322-1648) 6 (1), 939 (1883), Acts on land ownership in South-Western Russia in the XV - XVIII centuries (1407-1579) 4 (8), 766 (1907), Acts on land ownership in SouthWestern Russia in the XV - XVIII centuries. (1450-1575 6 (8), 621 (1911) [in Ukrainian]

2. M. Stryjkowski, Kronika Polska, Litewska, Zmudska i Wszystkiej Rusi (Warszawa, 1846)

3. K. Buczek, Wolun w dawnej kartografiji XV-XVIII w.-RW, (1935)

4. Z.L. Radzimiński, R Skobielski, B. Gorczak, Archiwum Książąt LubartowiczówSanguszków w Sławucie 1, 204 (1887), 3, 554 (1890), 4, 647 (1890), 7, 433 (1910)

5. G. Cioler, K. Zelechoweka, Ze studiow nad zalcseniami ogrodowymi Wolynia (IESK, R.VII, 19-46, 1939)

6. Á. Moravánszky, Competing Visions, Aesthetic Invention and Social Imagination in Central European Architecture (MIT Press, Cambridge, London, 1998)

7. K. Chodynicki, Kościół prawosławny a Rzeczpospolita Polska. Zarys historyczny 1370-1632, (1934)

8. J. Hofman, Bibliografia Wolynia (Rowne: RW, 2, 494-559, 1931)

9. J. Kłoczowski, Zakony na ziemiach polskich w wiekach średnich, Kościół w Polsce 1, 375-582 (1966), 2, 485-729 (1970)

10. Biuletyn Historii Sztuki.Index artykuiyw (1932-1981), BHS 1-4, (1982)

11. J. Gizycki, Spis klasztoryw unickich Bazylianow w wojewodstwie Wolynskim (Krakow, 1905)

12. J. Gizycki, Wspomnienie o tryniterach na Wolyniu, Podolu i Ukrainie przez wolyniaka (Krakow, 1909)

13. J.M. Giżycki, Spis klasztorów unickich Bazylianów w województwie Wołyńskiem (Kraków, 145, 1905)

14. Betley. Kostioi bernardunow w Zaslawin, BHS, 353-363, (1995)

15. J. Hofman, Przewodnik po Wolyniu (Warszaw, 67, 1938)

16. L. Grajewski, Bibliografia ilustracji w czasopismach polskich XIX i pocs.XX w. (do 1918 r.) (Warszawa, 554, 1972)

17. Prusiewicz, Klasztory katolickie w diecezji Łuckiej (Łuck, 20, 1922)

18. A.Sendulskij, Istoriciskaja svedenija o pravoslavnych cercvach i monastyrjach $\mathrm{v}$ g. Łucke. nyne nesuscestvujuscich Volynskie Eparch, Vedomosti 11, 13 (1872)

19. T. Ladeoberger, Notatki bibliograficzno (Tarnopol: RP, 1, 270-343, 1938)

20. Z. Kucielsка, Z. Tobiaszowa, Katalog rysunkow architektonicsnych ze zbioryw Muzeum w Krakowe, Cz.1. Rysunki Napolneona Ordy (Warszawa, 480, 1975)

21. H.N. Lohvyn, Architectural complex in Zymno. The dissertation for a scientific degree of the candidate of technical sciences, architecture (K.: manuscript, 137, 1948) [in Ukrainian]

22. S. Giedeon, Space, Time and Architecture, Fifth Edition (Harvard University Press. Cambrige -(Mass.), 1967)

23. J. Poplatek, J. Paszend, Slownik jezuitow artystow (Krakow, 298, 1972) 
24. K. Estreicher, Zestawienie przedmiotyw i autoryw w 32 tomach "Tygodnika Ilustrowanego" z lat 1859-1857 (Warszawa, 769, 1877)

25. Lustracje krolewszyzn ziem Ruskich, Wolynia, Podola i Ukrainy z pierwszej polowy XVII wieku, Wyd. Osiadlosc miasta Ostroga anno 1708 (RW, Rowne,7, 181-226, 1938)

26. J. Popiel SJ, Sakralny wyraz dawnych i współczesnych form architektury sakralnej, „Ruch Biblijny i Liturgiczny” 3, 225-229 (1984)

27. R. Tuomi, On the search for a national style, „Abacus” (rocznik Museum of Finnish Architecture, 57-96, 1979)

28. J. Danilewicz, Kościół i jego wnętrze w świetle przepisów prawno-liturgicznych (Kielce: Diecezjalny Fundusz Wydawniczy, 157-165, 1948)

29. L. Gnatiuk, M. Terletska, Aesthetics of shaping sacred space, Theory and practice of design, Collection of scientific papers, Technical aesthetics 11, 42-56 (2017). DOI: $10.18372 / 2415-8151.11 .11874$

30. L. Gnatiuk, Confessional affiliation and formation and development of sacred buildings of historical Volhynia, Ukrainian Academy of Arts: Research and scientificmethodical works 15, 169-176 (2008)

31. L. Gnatiuk, Spatial dimensions in Ukrainian sacred art, Technical aesthetics and design. Interdepartmental scientific and technical collection 9, 66-72 (2011)

32. L.R. Gnatiuk, Aesthetics of formation of sacred space in Ukraine, Theory and practice of design. Collection of scientific works 12, 69-77 (2017) DOI: 10.18372 / 24158151.12.12544 [in Ukrainian]

33. L.R. Hnatiuk, O.P. Oliynyk, Sacred space of the city, In the book Proceedings of the scientific conference "Lyubart readings", Scientific and information collection "Old Lutsk" LDIKZ 6, 322-332 (2010) [in Ukrainian]

34. Yu.I. Kryvoruchko, Regional features of the location of churches in Ukraine, Bulletin of the National University "Lviv Polytechnic": architecture 439, 55-62 (2202) [in Ukrainian]

35. Yu.I. Kryvoruchko, Territorial organization of religion in Ukraine in the 1990s, Historical country studies of Ukraine: collection of scientific works (Lviv, 2003, New York: Publishing House M.P. Krotz, 470-484, 2004) [in Ukrainian]

36. Yu.V. Ivashko, Baroque style in the architecture of Ukrainian churches, Man and the world 11-12, 12-15 (1997) [in Ukrainian]

37. R.B. Hnidets, Tradition and modernity in the church architecture of Lviv, Notes of Shevchenko Scientific Society, works of the Commission of Architecture and Urban Planning (Lviv: NTSh, CCLV, 299-312, 2008) [in Ukrainian]

38. B. Cherkes, Tradition and Identity in the New Ukrainian Church Architecture, News of the National University of Lviv Polytechnic: architecture 486, 71-91 (2003) [in Ukrainian] 